\title{
The relationship between patient satisfaction and effectiveness of insulin- based therapy for type 2 diabetes mellitus at Ulin Regional Public Hospital, Banjarmasin
}

\author{
Risya Mulyani*, Dedi Hartanto \\ ${ }^{I}$ Faculty of Pharmacy University of Muhammadiyah Banjarmasin \\ Jl. S. Parman. Kompleks RS Islam, Banjarmasin, Kalimantan Selatan 70114, Indonesia
}

Submitted: 20-10-2017

Reviewed: 03-02-2018

Accepted:16-04-2018

\begin{abstract}
Diabetes Mellitus (DM) can cause significant problems to the quality of life as it may increase the risk of complications. Dissatisfaction with therapy also contributes to its low effectiveness. Therapeutic satisfaction has an essential role in DM management, i.e., to optimize the effectiveness of the treatment. It is also believed to affect the decision-making process regarding patients' healthrelated issues. A routine assessment of the satisfaction of DM patients is useful for health professionals in identifying the potential problems experienced by those who are in the middle of DM treatment. This study aimed to determine the relationship between patient satisfaction and effectiveness of insulin-based therapy for type 2 DM at Ulin Regional Public Hospital, Banjarmasin. This research is a nonexperimental study with a cross-sectional design. The data were collected prospectively with purposive sampling method from the type 2 DM patients at the Pharmacy Installation of Ulin Regional Public Hospital, Banjarmasin. While the therapeutic satisfaction data were obtained using the Patient Satisfaction with Insulin Therapy (PSIT) questionnaire, the effectiveness of the therapy was identified by examining the HbA1c values. Fifty-six (56) respondents participated and filled in the questionnaire, and the answers were processed with bivariate analysis, namely the chi-square test. The results showed that the respondents' satisfaction with the treatments was mostly on a medium level according to 33 patients $(58.9 \%)$. However, only $3.6 \%$ respondents found the therapy effective (HbA1c <6.5\%). The remaining $96.4 \%$ thought that it was less effective in controlling diabetes. Based on the statistical analysis results, there is a significantly positive relationship between patient satisfaction and HbA1c value $([\mathrm{r}=0.828] ;[\mathrm{p}=0.000])$. There is also a significant positive relationship between patient satisfaction and the effectiveness of therapy in patients with type 2 diabetes at the Pharmacy Installation of Ulin Regional Public Hospital, Banjarmasin.
\end{abstract}

Keywords: diabetes mellitus, therapy satisfaction, and $\mathrm{HbA1c}$ value.

\section{Corresponding author:}

Risya Mulyani

Fakultas Farmasi, Universitas Muhammadiyah Banjarmasin

J1. S. Parman. Kompleks RS Islam, Banjarmasin, Kalimantan Selatan 70114

Email: reha_ai@yahoo.com 


\section{INTRODUCTION}

The World Health Organization (WHO) estimates that approximately 422 million adults developed Diabetes Mellitus (DM) in 2014. This number shows an increase from 108 million in 1980. $\mathrm{DM}$ and its complications pose significant economic damage for its sufferers, their families, health system, and the national economy due to the direct medical costs and loss of workability. "Diabetes is a complex, chronic illness requiring continuous medical care with multifactorial risk-reduction strategies beyond glycemic control" (American Diabetes Association (ADA), 2017, p. 51). International Diabetes Federation (IDF) predicts an increase in the number of people with DM in Indonesia from 9.1 million in 2014 to 14.1 million by 2035 (PERKENI, 2015a).

Complications from DM are preventable by controlling blood glucose levels. However, achieving a target for glycemic control is not easy even if the patient has been taking Oral Hypoglycemic Drug (OHD) or insulin. DM management can be implemented with four pillars, including pharmacological intervention with, for instance, OHD and insulin therapy (ADA, 2017). Early application of insulin is useful for reducing glucose toxicity, mortality, and morbidity, improving endogenous insulin efficiency, and preventing damage to pancreatic beta cells (Tsukube et al., 2015). Endogenous insulin resistance can occur due to chronic weight gain, which reduces the insulin response. Therefore, early insulin treatment is vital (You et al., 2017).

The many benefits of insulin treatment have led to its high application in DM therapy. However, there are some obstacles to its use including patients' fear of insulin injections, weight gain, and high cost. Even though earlier treatment may prevent immediate complications, these significant obstacles may cause patient dissatisfaction and noncompliance with the therapy. According to PERKENI (2015a), dissatisfaction and noncompliance, along with lack of knowledge about disease and treatment, contribute to low blood glucose control.

Regular assessment of patient satisfaction with DM treatment can significantly assist health professionals to identify the potential problems experienced by patients with ongoing DM therapy. This satisfaction has an essential role in DM management, particularly for optimum blood glucose control. It is also believed to have an effect on the effectiveness of therapy in these patients. According to Boels et al. (2017), elevated HbAlc and controlled glycemic levels in DM patients are crucial in determining patient satisfaction with the treatment.

\section{RESEARCH METHOD}

This research is a non-experimental study with a cross-sectional design. The data were collected prospectively from type $2 \mathrm{DM}$ patients that took insulin-based therapy at the Pharmacy Installation of Ulin Regional Public Hospital in Banjarmasin. The research subjects were determined using the following inclusion criteria: (1) male or female patients with type $2 \mathrm{DM}$ who received either single or combination insulin therapy and (2) signed the informed consent to participate in the study. They were also selected based on an exclusion criterion, i.e., type $2 \mathrm{DM}$ patients without $\mathrm{HbA1c}$ levels. Among the 93 subjects who met the inclusion criteria, 37 were excluded. The final total research subject was 56 patients.

\section{Data and Tools}

The research instruments were a health assessment sheet containing patient medical history, Patient Satisfaction with Insulin Therapy (PSIT) questionnaire to measure the satisfaction with the therapy method, prescription, medical record, and laboratory examination result.

\section{Research Procedure}

The research procedure included directing the patients coming to the Polyclinic of Internal Medicine to meet the pharmacist after being examined by doctors. At the time of this meeting, they were provided with an explanation of the purpose of the meeting and asked for their willingness to 
engage in the research. The willing patients were given informed consent. Afterward, they answered some general questions asked during the interviews and filled in the PSIT questionnaire to assess the degree of their satisfaction with the insulin-based type 2 DM treatment they were taking at Ulin Regional Public Hospital, Banjarmasin. The sampling was performed on type 2 DM patients who came for insulin-based therapy during May-August 2017. The data were identified and analyzed to provide an overview of patients' sociodemographic characteristics, types of therapy, and satisfaction with insulin therapy at Ulin Regional Public Hospital, Banjarmasin. The analysis attempted to determine the relationship between the duration of the disease, the type of therapy, and patient satisfaction, as well as the relationship between satisfaction with therapy and the HbA1c levels in patients with type 2 DM at Ulin Regional Public Hospital, Banjarmasin.

\section{Data Analysis}

The scale used to measure patient satisfaction with therapy was categorical, i.e., ordinal. The level satisfaction was defined based on mean and standard deviation into three categories, namely low $(\leq$ mean-SD), medium (mean-SD $<x \leq$ mean+SD), and high $(>$ mean+SD). Mean is the average score of the satisfaction of all respondents, SD is standard deviation, and $x$ is the total score of each respondent's satisfaction. The measurement scale used for HbA1c was also categorical, i.e., ordinal. The categories were good $(<6.5)$, medium $(6.5-8)$, and poor $(>8)$.

The respondents' answers were collected and quantified based on the scores of the corresponding questions (scoring). These data were tabulated to facilitate the analysis. The univariate analysis aimed to describe the individual characteristics, the degree of satisfaction, compliance level, and $\mathrm{HbA} 1 \mathrm{c}$ level statistically, i.e., the minimal and maximal value, mean, SD, and data frequency of each parameter. In this study, the chi-square test aimed to identify the relationship between patient satisfaction with therapy and $\mathrm{HbA} 1 \mathrm{c}$ level.

\section{RESULTS AND DISCUSSION}

This study aimed to describe patient satisfaction and compliance with insulin-based type $2 \mathrm{DM}$ therapy, as well as to identify the relationship between patient satisfaction and $\mathrm{HbA} 1 \mathrm{c}$ level. It was performed prospectively to type $2 \mathrm{DM}$ patients who received insulin-based therapy at the Pharmacy Installation of Ulin Regional Public Hospital in Banjarmasin from May to August 2017 (four months). These patients were selected as research subjects using purposive sampling method, and at the end of the study, fifty-six (56) respondents met the inclusion and exclusion criteria.

The data of patient satisfaction and compliance with therapy were obtained from the questionnaire filled by the respondents. The patient satisfaction was based on the PSIT questionnaire. The sociodemographic data were collected from the health assessment sheet and interview with respondents. Meanwhile, the history of patient's therapy and HbAlc level were obtained from the clinical pathology laboratory. The descriptive analysis resulted in a set of data consisting of sociodemographic characteristics (i.e., age and sex), type of therapy, patient satisfaction, compliance with therapy, and $\mathrm{HbA1c}$ value.

\section{The characteristics of the respondents}

A descriptive analysis was used to provide an overview of the characteristics of the respondents by age, sex, and type of therapy. Respondents were grouped by type of therapy into those with single therapy category (i.e., respondents who used insulin alone) and the ones with combination therapy (i.e., respondents who combined insulin treatment with Oral Hypoglycemic Drugs (OHD)).

Table I shows that most of the respondents (30 patients or 53.6\%) are female, younger than 50 years old ( 22 patients or $39.3 \%$ ), and takes combination therapy (54 patients or $96.4 \%$ ). The highest percentage of type 2 DM case in this study is found in patients aged 50-59 years old. In developing countries, the majority of type 2 DM patients is female (Migdalis et al., 2015), as affirmed in this research. According to Migdalis et al., (2015), the prevalence of type 2 DM in men is higher than in 
women, but there are times when the contrary prevalence occurs. A higher prevalence of type $2 \mathrm{DM}$ in women is specifically found in women with previous Gestational DM (ADA, 2017).

Table I. The characteristics of respondents (Patients with type 2 DM) by age, sex, type of therapy at the pharmacy installation of Ulin regional public hospital, Banjarmasin

\begin{tabular}{cccc}
\hline Categories & Groups & $\begin{array}{c}\text { Total } \\
(\mathbf{n})\end{array}$ & $\begin{array}{c}\text { Percentage } \\
(\mathbf{\%})\end{array}$ \\
\hline \multirow{2}{*}{ Sex } & Male & 26 & 46.4 \\
& Female & 30 & 53.4 \\
\multirow{3}{*}{ Age } & $<50$ years old & 22 & 39.3 \\
& $50-59$ years old & 20 & 35.7 \\
\multirow{3}{*}{ Type of therapy } & 60-69 years old & 11 & 19.6 \\
& $\geq 70$ years old & 3 & 5.4 \\
& Single & 2 & 3.6 \\
& Combination & 54 & 96.4 \\
\hline
\end{tabular}

The incidence rate of type $2 \mathrm{DM}$ varies between males and females. They have the same chance of developing DM. However, the risk factors dictate that women have a higher chance due to a higher increase of Body Mass Index (BMI). Hormonal process (i.e., premenstrual syndrome) in postmenopausal women accumulates body fat much quickly, which increases their risk to DM (Ramadhan and Marissa, 2015).

Table II shows that most of the type 2 DM patients in this study are in combination therapy, while only a few of them takes single therapy. In addition to type of therapy, this table also lists the medicines used by patients with insulin-based type 2 DM therapy at the Pharmacy Installaion of Ulin Regional Public Hospital, Banjarmasin.

Treatment with insulin is absolutely necessary for type $1 \mathrm{DM}$. Type $2 \mathrm{DM}$ patients are prescribed with insulin during pregnancy, as well as when experiencing metabolic decompensation, receiving high dose steroid therapy, and planned to undergo surgery where lower blood glucose level is a requirement. DM patients with metabolic decompensation use insulin only if the patients experience the following cases: weight loss, Fasting Blood Glucose (FBC) $>250 \mathrm{mg} / \mathrm{dL}$, random blood glucose $>300 \mathrm{mg} / \mathrm{dL}$, and $\mathrm{HbA} 1 \mathrm{c}>9 \%$, and if they have undergone therapy previously (PERKENI, 2015b).

According to Tsukube et al., (2015), patients receiving early and more aggressive treatment with insulin show better clinical outcomes especially related to glucotoxicity, which is presented by the improvement of pancreatic $\beta$ cell function. Oral hyperglycemia drugs does not work quite efficiently in treating glucotoxicity in many type 2 DM patients. To achieve a desired treatment goal, the insulin regimen has to be adjusted to the needs and comforts of each patient. Rapid-acting insulin such as insulin aspart and lispro can produce higher levels of insulin serum and have a shorter duration of action. This type of insulin results in low postprandial glucose levels and reduces the duration of postprandial hyperglycemia significantly, which diminishes severe hypoglycemic events in type $2 \mathrm{DM}$ patients. Long-acting insulin is usually prescribed for type 2 DM patients with $\mathrm{HbA1c}>7.5-10 \%$. 
Table II. The medicines used by type 2 DM patients who received insulin-based therapy

\begin{tabular}{clcc}
\hline $\begin{array}{c}\text { Type of } \\
\text { Therapy }\end{array}$ & \multicolumn{1}{c}{ Names of Medicine } & $\begin{array}{c}\text { Total } \\
\text { Respond } \\
\text { ents }\end{array}$ & Percentage \\
\hline Single & $\begin{array}{l}\text { Premixed insulin } \\
\text { Long-acting insulin } \\
\text { Long-acting insulin, Rapid-acting } \\
\text { insulin }\end{array}$ & 1 & $1.79 \%$ \\
& $\begin{array}{l}\text { Long-acting insulin, Metformin } \\
\text { Long-acting insulin, Acarbose }\end{array}$ & 4 & $4.79 \%$ \\
Combination & $\begin{array}{l}\text { Long-acting insulin, Sulfonylureas } \\
\text { Premixed insulin, Sulfonylureas }\end{array}$ & 2 & $10.7 \%$ \\
& $\begin{array}{l}\text { Rapid-acting insulin, Long-acting } \\
\text { insulin, Acarbose }\end{array}$ & 1 & $3.55 \%$ \\
& $\begin{array}{l}\text { Rapid-acting insulin, Long-acting } \\
\text { insulin, Metformin }\end{array}$ & 8 & $1.79 \%$ \\
& $\begin{array}{l}\text { Long-acting insulin, Metformin, } \\
\text { Acarbose }\end{array}$ & 1 & $1.79 \%$ \\
& $\begin{array}{l}\text { Premixed insulin, Metformin, } \\
\text { Acarbose }\end{array}$ & 1 & $1.79 \%$ \\
& $\begin{array}{l}\text { Premixed insulin, Metformin, } \\
\text { Thiazolidinedione } \\
\text { Rapid-acting insulin, Long-acting } \\
\text { insulin, Metformin, Acarbose }\end{array}$ & 4 & $1.79 \%$ \\
\hline
\end{tabular}

Patient satisfaction with insulin-based therapy (PSIT)

The PSIT questionnaire is one of the instruments used to measure the satisfaction of DM patients with insulin-based therapies. It analyzes the two critical contributing factors to patient satisfaction, namely convenience or ease of use and social comfort.

Gerber et al., (2001) explain that PSIT questionnaire consists of 15 items of questions, and the responses to these questions are categorized using five-point Likert scale, namely strongly disagree, disagree, do not know, agree, and strongly agree. In this research, the categorization was performed and then summed into the overall value of the respondents' satisfaction. The mean \pm SD was then calculated from this value as a reference for classifying the degree of satisfaction. The results showed that the mean $\pm \mathrm{SD}$ was $53.57 \pm 12.88$. The distribution of the satisfaction classification is presented in Table III.

Table III. Respondents' satisfaction with insulin-based therapy

\begin{tabular}{cccc}
\hline Total & Degrees of Satisfaction & $\begin{array}{c}\text { Number of } \\
\text { Respondents } \\
(\mathbf{n = 5 6 )}\end{array}$ & Percentage \\
\hline Low & 8 & 14.3 \\
Medium & 33 & 58.9 \\
High & 15 & 26.8 \\
& $\mathbf{5 6}$ & $\mathbf{1 0 0}$ \\
\hline
\end{tabular}


Table III shows that the respondents' satisfaction with their therapy was averagely medium. Black et al., (2006) also state that the PSIT questionnaire is divided into two subscales, namely convenience/ease of use and social satisfaction. With appropriate adjustments for positive and negative questions, such as No. 3 and 4, the sum of the Likert scores of all 15 questions can give an overall satisfaction score of 15-75.

\section{The HbA1c levels of the respondents}

Decreased HbAlc level has been proven to reduce microvascular complications in diabetic patients and is associated with a reduced risk of myocardial infarction and other fatal cardiovascular events. According to the American Diabetes Association (ADA), the recommended HbA1c level for adults with diabetes is $<7.0 \%$. Meanwhile, the American Association of Clinical Endocrinology (AACE), the American College of Endocrinology (ACE), and International Diabetes Federation (IDF) recommend $\mathrm{HbA} 1 \mathrm{c}$ level of $\leq 6.5 \%$ (Karnchanasorn et al., 2016).

This research used $\mathrm{HbA1c}$ as an instrument to represent the success of the therapy. HbA1c level examination is essential for DM patients to see their glycemic control. For most diabetic patients, the ideal target for $\mathrm{HbA} 1 \mathrm{c}$ is below $7 \%$. Any $1 \%$ decrease in $\mathrm{HbA} 1 \mathrm{c}$ reduces the risk of microvascular complications by $40 \%$ and death by $21 \%$ (Bardisi et al., 2015). The results in Umpierrez et al. (2014) strongly recommend repeated therapies for patients with $\mathrm{HbA} 1 \mathrm{c}$ of $<7 \%$. If the $\mathrm{HbAlc}$ level is between $7 \%$ and $9 \%$, patients have to return to oral antidiabetic therapy and half of the basal insulin dose. Meanwhile, if the $\mathrm{HbA1c}$ level is $>9 \%$, then they have to return to oral antidiabetic therapy and $80 \%$ of the basal insulin dose. The HbA1c levels of the respondents are described in Table IV.

Only $3.6 \%$ of 56 respondents were assumed to have a well-controlled glycemic level (HbA1c $<6.5 \%$ ), whereas the remaining $96.4 \%$ were categorized as not well-controlled. The low glycemic control in this study is similar to previous research where $85 \%$ of the respondents have HbAlc of less than $6.5 \%$ (Ramadhan and Marissa 2015).

Table IV. The $\mathrm{HbA}_{1 \mathrm{c}}$ level of the respondents in insulin-based therapy

\begin{tabular}{clcc}
\hline No & \multicolumn{1}{c}{$\mathbf{H b A}_{\mathbf{1 c}}$} & $\begin{array}{c}\text { Number of } \\
\text { Respondents } \\
(\mathbf{n = 5 6})\end{array}$ & Percentage \\
\hline 1 & Good $(<6,5 \%)$ & 2 & 3.6 \\
2 & Medium $(6.5 \%-8 \%)$ & 12 & 21.4 \\
3 & Bad $(>8 \%)$ & 42 & 75.0 \\
& Total & $\mathbf{5 6}$ & $\mathbf{1 0 0}$ \\
\hline
\end{tabular}

To understand the relationship between patient satisfaction with the therapy and the HbA1c level, this research used bivariate analysis, i.e., chi-square test. As presented in Table V, there is a positive relationship between satisfaction, treatment method, and HbAlc level $(r=0.828)$. In another word, the higher the patient satisfaction, the better the HbA1c level. Referring to the $r$ coefficient, there is a strong correlation between patient satisfaction and HbA1c level. High satisfaction with the therapy is always followed by a good HbA1c level. On the contrary, a low satisfaction leads to a bad HbA1c level. 
Table V. The relationship between patient satisfaction and effectiveness of therapy based on HbA1c level

\begin{tabular}{|c|c|c|c|c|c|}
\hline \multirow[b]{2}{*}{ Satisfaction Levels } & \multicolumn{3}{|c|}{ HbA1c } & \multirow[b]{2}{*}{$\mathbf{R}$} & \multirow[b]{2}{*}{$\mathbf{P}$} \\
\hline & $\begin{array}{c}\text { Good } \\
(<6.5 \%)\end{array}$ & $\begin{array}{c}\text { Medium } \\
(6.5 \%-8 \%)\end{array}$ & $\begin{array}{c}\text { Low } \\
(>8 \%)\end{array}$ & & \\
\hline Low & 0 & 0 & 22 & & \\
\hline Medium & 11 & 16 & 26 & 0.828 & 0.000 \\
\hline High & 34 & 0 & 0 & & \\
\hline
\end{tabular}

The results showed that respondents with high satisfaction certainly had a good HbAlc level, whereas the ones with low satisfaction had a bad HbAlc level. This finding is in line with Mora et al., (2017) where patient satisfaction and perception of the treatment are strongly related to compliance with therapy and the clinical outcome.

According to Tsukube et al., (2015), aside from patient satisfaction and health status, a key to a successful therapy is a decrease in HbA1c level down to $7 \%$. Therefore, the success of a DM treatment is strongly determined by a decrease of $\mathrm{HbAlc}$ level and early use of insulin.

\section{CONCLUSION}

There is a significant positive relationship between patient satisfaction with therapy and $\mathrm{HbA} 1 \mathrm{c}$ level ([r=0.828]; $[\mathrm{p}=0.000])$.

\section{ACKNOWLEDGMENT}

Authors would like to thank the Indonesian Ministry for Research, Technology, and Higher Education for their funding under the scheme of Research Grant for Young Lecturer in 2017. We would like to acknowledge the Rector of Universitas Muhammadiyah Banjarmasin for the moral support during this research.

\section{REFERENCES}

American Diabetes Association (ADA), 2017. Standards of Medical Care in Diabetes-2017: Summary of Revisions , Diabetes Care, 40(Supplement 1), pp. S4-S5.

Bardisi, W., Khorsheed, M., Magliah, F. and Magliah, A, 2015. 'Efficacy of insulin analogues in diabetic patients attending primary care centers', Saudi Medical Journal, 36(7), pp. 829-833.

Black, C., Cummins, E., Royle, P., Philip, S. and Waugh, N, 2006. The clinical effectiveness and cost effectiveness of inhaled insulin in diabetes mellitus: A systematic review and economic evaluation A health technology assessment commissioned by the HTA Programme on behalf of the National Institute for Health and Cli. Aberdeen. Available at: https://www.nice.org.uk/guidance/ta113/documents/diabetes-type-1-and-2-inhaled-insulinassessment-report2.

Boels, A. M., Vos, R. C., Hermans, T. G. T., Zuithoff, N. P. A., Müller, N., Khunti, K. and Rutten, G. E. H. M, 2017. What determines treatment satisfaction of patients with type 2 diabetes on insulin therapy? An observational study in eight European countries, BMJ Open, 7(7), p. e016180.

Gerber, R. A., Cappelleri, J. C., Kourides, I. A. and Gelfand, R. A, 2001. Treatment satisfaction with inhaled insulin in patients with type 1 diabetes: a randomized controlled trial, Diabetes care, 24(9), pp. 1556-9. 
Karnchanasorn, R., Huang, J., Ou, H.-Y., Feng, W., Chuang, L.-M., Chiu, K. C. and Samoa, R, 2016. Comparison of the Current Diagnostic Criterion of HbA1c with Fasting and 2-Hour Plasma Glucose Concentration', Journal of Diabetes Research, 2016, pp. 1-11.

Migdalis, I., Leslie, D., Mavrogiannaki, A., Papanas, N., Valensi, P. and Vlassara, H, 2015. Diabetes Mellitus 2014, International journal of endocrinology, 2015, p. 845759.

Mora, P., Buskirk, A., Lyden, M., Parkin, C. G., Borsa, L. and Petersen, B, 2017. Use of a Novel, Remotely Connected Diabetes Management System Is Associated with Increased Treatment Satisfaction, Reduced Diabetes Distress, and Improved Glycemic Control in Individuals with Insulin-Treated Diabetes: First Results from the Personal Diabetes Management Study', Diabetes Technology and Therapeutics, 19(12), p. dia.2017.0206.

Pengurus Besar Perkumpulan Endokrinologi Indonesia (PB PERKENI), 2015a, Konsensus Pengelolaan dan Pencegahan Diabetes Melitus tipe 2 di Indonesia 2015, Konsensus Pengelolaan dan Pencegahan Diabetes Melitus tipe 2 di Indonesia 2015. Jakarta: PB Perkeni. Available at: http://pbperkeni.or.id/doc/konsensus.pdf.

PERKENI, 2015b. Konsensus Penggunaan Insulin. Jakarta: PB PERKENI. Available at: http://pbperkeni.or.id/newperkeni/wp-content/plugins/downloadattachments/includes/download.php?id=102.

Ramadhan, N. and Marissa, N. (2015) 'Karakteristik Penderita Diabetes Melitus Tipe 2 berdasarkan Kadar Hba1c di Puskesmas Jayabaru Kota Banda Aceh, Sel, 2(2), pp. 49-56.

Tsukube, S., Ikeda, Y., Kadowaki, T. and Odawara, M, 2015. Improved Treatment Satisfaction and Self-reported Health Status after Introduction of Basal-Supported Oral Therapy Using Insulin Glargine in Patients with type 2 Diabetes: Sub-Analysis of ALOHA2 Study', Diabetes Therapy. Springer Healthcare, 6(2), pp. 153-171.

Umpierrez, G. E., Reyes, D., Smiley, D., Hermayer, K., Khan, A., Olson, D. E., Pasquel, F., Jacobs, S., Newton, C., Peng, L. and Fonseca, V, 2014. Hospital Discharge algorithm based on admission $\mathrm{Hba} 1 \mathrm{c}$ for the management of patients with type 2 diabetes, Diabetes Care, 37(11), pp. 2934-2939.

World Health Organization (WHO), 2016. Global Report on Diabetes, Global Report on Diabetes. Geneva, Switzerland: WHO Press. Available at: http://www.who.int.

You, D., Nilsson, E., Tenen, D. E., Lyubetskaya, A., Lo, J. C., Jiang, R., Deng, J., Dawes, B. A., Vaag, A., Ling, C., Rosen, E. D. and Kang, S, 2017. Dnmt3a is an epigenetic mediator of adipose insulin resistance, eLife, 6, pp. 2-3. 